\title{
A semmit mondás változatai és jelentései Tolnai Ottó árvacsáth verseiben
}

Tolnai Ottó árvacsáth versei önmagában a Csáth Géza-i élet és mú költói szóba hozásával, a versbeszédben megszólaló - a versbeszéd

által létesüló - szubjektum rétegezettségével, a csáthi életútból, életmúból, Tolnai Kosztolányi-olvasataiból, valamint Tolnai korábbi lírai tapasztalataiból részesüló árvacsáth énjének megosztottságával, a hang egységességének kétségbe vonásával, a beszélớ énnek a maga beszédére való szüntelen reflexiójával, magával a beszédmóddal a költối szólást - helyét, módját, lehetốségeit is - tárgyukká teszik. Tolnai Ottó költészetéról megállapitható, hogy az egyre pontosabb beszéd lehetôségének hite helyett a végeérhetetlen bốvités, a folyamatos hozzátétel, a kitérés, a mellébeszélés, a semmis dolgok körül való beszéd jellemzi; az elhallgatást, az elnémulást, a csönd rettenetét behelyettesitố szólás, voltaképpen a költối beszédnek a némaság határán egyensúlyozó fenntartása.

A z árvacsáth verseskötetnek nem csupán Csáth Géza és Kosztolányi Dezső életmüvéhez való költöi viszonyulás a tétje, hanem a Vidéki Orfeusz, a Wilhelm-dalok vagy $A$ kisinyovi rózsa címü Tolnai-kötetek versbeszédével együtt (többek között) a költői szólás státusára, orfikus karakterére kérdez rá.

A semmi költői kutatása, szóba hozása, a semmit mondás gyakorlása Tolnai Ottó költészetének visszatérő jellemzője, ahogy visszatérően kutatott motívuma a Tolnai-szakirodalomnak is. Bányai János korai, 1973-as írásában A semmiségek custosa címmel ír Tolnairól (Bányai, 1973, 31. o.), Thomka Beáta Tolnai-monográfiája épp az árvacsáth kapcsán kezd értekezni ,a költői szubjektumnak a poésie pure-ért, a mallarméi semmiről sem szóló könyv eléréséig, a jelentéktelenségek begyüjtéséért és megtisztításukért kifejtett" igyekezetéről (Thomka, 1994, 134. o.), s az 1992-es Versek könyve címü Tolnai-kötetet tárgyaló Csak tárgy s tény legyen címü fejezet egészében ,, a lét a semmis nyomokban mutatkozik a legszivesebben" gondolatának a kifejtése; Fekete J. József a semmi, a semmiségek előfordulásait, szövegváltozásait katalogizálja (Fekete J., 2010), és a semmi változataival együtt szinte végeérhetetlenül sorolhatók a Tolnai-szakirodalom vonatkozó hivatkozásai. Az egzakttal szemben a körülhatárolatlan, a szabályossal szemben a formátlan, a beazonosított valamivel szemben a beazonosítatlan semmi izgatja Tolnait voltaképpen pályája kezdetétől, de különösen tudatosan az 1980-as Világpor címü kötet óta. Az amorf jellegü, az egyedi azonosság nélküli létezők, az eltűnés határán lévő jelenségek. Visszatérő motívuma a por, a liszt, a rizomatikus gyökerü csicsóka és a formátlanság netovábbja, a karfiol, vagy témává lesz a nyelv nélkül megszólaló harang hangjának dicsérete a kilencvenes években írott és 2001-ben megjelent Balkáni babérban, vagy a kőfejtőivel a velencei építészetet kiszolgáló kis adriai sziget, Vrnik sorsa, amelynek lakói 
a szó szoros értelmében a maguk alól bányásszák és adják el a szigetüket, hagyják széthúzni a szigetük testét, a hiányt tartva meg maguknak (a gyönggyel töltött browning címü vers 1984-es keltezésü, és az 1992-es Versek könyvében jelent meg).

Mindehhez a hallgatás, a költői beszéd fölszámolása közelében álló nyelvet létesít (a 2001-es Balkáni babér címü kötet a vers elnémulását, a hosszú csend után való megszólalást is tematizálja), alulstilizált, roncsolt, a jelentéslétesítést folyton kisiklató, kitérőivel a megszólalás szavához, a hallgatást megszakító szóhoz folyton visszatérő, attól tulajdonképpen valamiféle célhoz eljutni nem tudó költői beszéd jellemző költészetére. Gyakori alakzata ennek a beszédnek a paradoxon, és a jelentésadás bizonytalansága legfeljebb egy-egy hétköznapi tárgy, mozdulat, jelenség motívummá emelésekor csökken.

Ilyen költői világlétesítés és költői nyelvkeresés jellemzi az 1992-ben megjelent árvacsáth kötetet is. A kötet második verse voltaképpen sajátos ars poeticaként olvasható, és a kicsit mondásról, a semmit mondásról beszél (címe nincs a hagyományos értelemben, hiszen a kötet minden verse az árvacsáth címet viseli):

nem sül ki a szemed

szokták volt mondani

ha netán nagyot találtam mondani

és én máris rettegtem

a kis véres énekestojás

sisteregni kezd a csonttégelyben

sül ki

sül ki a szemem

azóta nem győzök kicsit mondani

a semmit

munka közben egy selyemszálra kötött

hangyát sétáltatok papirosaimon

szórakozni is csak bolhacirkuszban

tollam moccanatai abszolút semmisek

homályos gyerekkori emlékek

valaki átment az utcán és felsértette

egy füszál köszörült árnyéka ilyesmik

és mégis érzem sül ki a szemem

sül ki

akárha az isten forró tenyerébe

talált volna tojni a kis énekes

(Tolnai, 1992a, 6. o.)

A szem és a látás természetesen nem véletlenül kerül itt szóba, Csáth más vonatkozások mellett (Szabadka, Kosztolányi) azért lesz fontos Tolnai számára, mert Csáth úgy lát, azt látja, olyan látásra van mersze, aminek elmondására nincs adekvát nyelv, ha pedig mégiscsak lenne, az azon a nyelven való beszédnek a befogadása lenne elviselhetetlen. Egy másik árvacsáth-versben a tollat a szikével hozza kapcsolatba, mindkettővel durva sebeket lehet ejteni, ahonnan már csak néhány merész asszociációs ugrás szükséges, hogy a szikével ejtett, majd sebtapasszal leragasztott sebtől eljussunk az elviselhetetlen írást azonnal rózsaszín flastrommal leragasztó elodázhatatlan mozdulatig:

le kell tapasztani momentán

ő (a mindentlátó) se lássa

a fekete sort

flamingószín (ultraviola) flastrommal 
kell letapasztani a fekete sorokat

a lét fertelmes

a lét fertelmes fertelmének levecse

ne üssön át

(Tolnai, 1992a, 12-13. o.)

A rózsaszín flastrom motívuma már egy 1986-os szegedi irodalmi esten szóba kerül, ennek a beszélgetésnek a szerkesztett anyaga aztán Rózsaszín flastrom címmel a Szajbély Mihály által szerkesztett Beszélgetések vajdasági írókkal alcímű kötet címadó írása lesz, és a Tolnai-szakirodalom talán legtöbbet hivatkozott szövege, föképp Tolnainak az Adriához füződő önidentifikációs kijelentése okán. Ebben a beszélgetésben hivatkozik Csáth naplóira, benne a rózsaszín flastrommal leragasztott sorokkal: „Naplóinak fekete füzeteit lapozgatva egy különös apróság ragadta meg figyelmemet. Egy helyen ragtapasszal (rózsaszín flastrommal) húzta át, takarta, rejtette el feljegyzését. Mi lehet alatta?! Istenem, milyen sebet rejtettek el itt?! Gyorsan fel kellett volna szakítanom a flastromot - de gyermekkoromban is mindig féltem lehúzni sebeimről ezeket a rózsaszín szalagokat, amiket már szinte azonosnak éreztem rózsaszín bőrömmel...

Azért döbbentem meg Csáth fekete füzetében, fekete tintával írt, végig - szép kézírásán, a rózsaszín flastromon, mert néhány éve egy megrázó levelet kaptam a törökkanizsai elmegyógyintézetben lévő gyermekkori barátomtól (aki különben szerepel Ördögfej címü regényemben, és ebben $A$ park címüben is). A levélben elmesélte elválásunk utáni életének borzalmait - és mikor már levelében úgy tűnt, hogy megérintetik a végső kérdés: a lét borzalma: rózsaszín flastormmal ragasztotta le a sorokat..." (Tolnai, 1995, 67. o.).

A versek énjeként megnevezett árvacsáthot elmondhatatlan hiányok és elmondhatatlan többletek bírják szóra és teszik beszédképtelenné. Hiány az Adria, hiány az azúr teljességének a hiánya, hiány a másik távol lévő teste, a saját test örömtől való megfosztottsága, a többlet pedig a látott, tapasztalt vagy saját kézzel okozott borzalmak, szenvedések bősége, és hogy még paradoxabb legyen a helyzet, van, amikor a hiány és a bőség, a gyönyör és a szenvedés szétválaszthatatlanul együtt van jelen, elmondhatatlanul. Végtére is maga a testi lét a megoldhatatlan probléma, a test egyszerisége, térbe zártsága, időnek kitettsége: hogy a test mindig egyetlen helyhez kötött, hogy elzárható, megsérthető, romlékony. Ezen tủnődik a versbe írt Csáth és Kosztolányi, a virágvasárnaptól nagypéntekig tartó egész életről:

szép életrajzod lesz désiré mondtam

egyetlen hét lesz az életed

nagyhét

de arról nem tettem említést míg désirét öleltem

hogy az én életem annak a hétnek csupán egy napja lesz

(Tolnai, 1992a, 44. o.)

A Krisztus-utalások, az angyalok sokszori említése a földi testbe zárt emberrel szemben valami más lehetőségeként kerülnek szóba, mint ahogy egyéb köztes, az ismert kategóriákon kívüli létezők, dolgok is gyakran a költői beszédet próbára tevő entitásokként kerülnek szóba. Ezekre használja az árvacsáth lírai énje a „sefüsefa: semsemmi” kifejezést (Tolnai, 1992a, 29. o.).

A költői (és az értelmezői) hagyománnyal való polémiára, a költői beszédről való további reflexióra is módot ad Tolnai számára az árvacsáthban szóhoz juttatott sajátos Csáth-, illetve Kosztolányi-figura. Jellemzően a Csáth- és Kosztolányi-életrajzokból ismert, leginkább a kamaszkori lelkesült, tervezgető és cselekvő együttlétek a költői megszólalás helyzetei, vagy ha a felnőttkori tapasztalatok is megidéződnek, akkor is 
bennük munkálnak, sajátos ellentétként az gyermekkor és ifjúkor naiv reményei. Így az ifjú Csáth és Désiré „,a poézis mibenlétéről" vitáznak, Petőfiért rajonganak, de míg a versbeszédben létesülő ifjú Csáth (a nagyot mondás hevében) „a vészre összpontosít”, „,amely még ma lesújt a világra miként a mészáros taglója lesújt az ökörnek szarva közé" (A helység kalapácsa-parafrázissal ugyanakkor parodizálva, vissza is vonva ezt a nagyot mondást), addig a versbéli Désiré, Kosztolányi az ,izé” szót állítja középpontba Petőfi életmüvéből, illetve az ,,izét mint olyant", úgyszintén $A$ helység kalapácsából idézve a „Csak én tudom ennek okát, / Én, kit földöntúli izék / Földöntúli izékbe avattak" sorokat, és a magyar költészet központi mozzanataként határozza meg a három sort (Tolnai, 1992a, 51. o.), a „linkség”, a pontatlanság dicséretét mondva, voltaképpen a behelyettesítő beszédet, a mellébeszélést láttatva vállalható magatartásként, a semmis, haszontalan tetteket, kezdeményezéseket, mániákat láttatva vállalhatóként, esélyt adóként az értelmesnek tartott nagy cselek-

vésekkel szemben. Így lesz a bélyeggyüjtés, a lombfürésszel való barkácsolás meg persze a diáklap, az ELÖRE szerkesztése kiemelten fontos cselekvés - szemben a felnőttek világában fontosnak tartott tettekkel.

Így veszi át a normális, ámde durva valóság helyét a hallucináció:

az ágy alatt aludtam ismét

és tényleg jöttek értem

rám tekerték

durván rám tekerték szárnyaim

és összekötötték őket hátul

mint mocskos bolondzubbony lebenyeit

összekötötték hátul szárnyaim

(Tolnai, 1992a, 71. o.)

Az árvacsáthban a prekoncepcióktól mentes, a gyermekkorból származó, a felnőttek tudásával még nem azonosuló percepció, a Wilhelm-dalok kötetben pedig a normálistól eltérő bolond percepciója képes kiszabadulni a ráció, a „valóság” kényszerzubbonyából. Mindkettőhöz szabálytalan, illetve szabályait folyton újraíró nyelv társul.

Ezzel szemben a pontosság, a tủ pontossága a kivédhetetlen veszéllyel van kapcsolatban, a kikerülhetetlen kényszerek a pontosak:

az a szűk cső gyerekkori álmomból

a kőlyuk tele záp gesztenyével

egyszerüen csak folytatódott

szükült

az lett az életem
A költói (és az értelmezôi)

hagyománnyal való polémiára, a költói beszédról való további reflexióra is módot ad Tolnai számára az árvacsáthban szóhoz juttatott sajátos Csáth-, illetve Kosztolányi-figura. Jellemzóen a Csáth- és Kosztolányi-életrajzokból ismert, leginkább a kamaszkori lelkesült, tervezgetó és cselekvố együttlétek a költói megszólalás helyzetei, vagy ha a felnóttkori tapasztalatok is meg-

idézódnek, akkor is bennük munkálnak, sajátos ellentétként az gyermekkor és ifjúkor naiv reményei. 
az a szük cső

nem lehet visszafordulni

egy tüben nem lehet

(Tolnai, 1992a, 103. o.)

A halál pedig a nyelv végleges elvesztésével mondódik ki, a kilincshez odafagyott vagy a tőből kimetszett nyelv képével (a nincs kilincs hangutánzó jellegü ismétlésével a nyelv nélküli harang motívumát is megidézve):

nyelvemmel kellene illetni most

ám hol lelnék itt egy rézkilincset

itt ahol egyáltalán nincs kilincs

nincs kilincs árvacsáth

nyelvemmel kellene illetni

gyerekkoromban minden tizenharmadikán ezt tettem

nyelvemmel illettem nagykapunk rézkilincsét

hagytam ráfagyjon (hegesztődjön)

kis dózsa

(désiré nevezett így egyszer ahogy végignézte)

kis dózsa türtem

vártam valaki hirtelen kinyissa

kitépje gyökerestől

vagy ha már olyan szépen kiöltöttem

a hibbant borbély

(már csak hullákat borotváltattak vele)

tőből kimesse

nyelvemmel kellene illetni

ám hol lelnék itt rézkilincset

itt ahol egyáltalán nincs kilincs

nincs kilincs árvacsáth

lám valamihez mégis odafagyott

látom érkezni gyerekkorom hibbant borbélyát

istenem azóta itt tartják szegényt a zárt osztályon

mintha csak valaki tudta volna

egyszer majd engem is idehoznak

s akkor majd szükség lesz a hibbant borbélyra

hogy kivágja nyelvem

s majd szépen megborotválja borzalmas hullám

(istenem én még a hullámra sem tudtam vigyázni)

(Tolnai, 1992a, 87. o.)

A félelem és a szorongás költői megjelenítésének változataiban bővelkedik az egész Tolnai-költészet, és ezek jelenléte csak ritkán kap egyetlen beazonosítható okot, a félelem és szorongás oka épp a beazonosíthatatlan állandóan jelen lévő semmi. Ha a félelem és szorongás kapcsán el is kezd épülni és felismerhetővé válik valamilyen, az értelmezés folyamatát megnyugtatóan lezáró, behelyettesíthető értelem, akkor azt gyorsan kioltja egy paradoxon, vagy a mellébeszélés, a bővítés, a kitérö labirintusaiban siklik ki, kerül vakvágányra a jelentéslétesítés. A létező világban kínálkozó, változat jellegükben egymást kizáró megoldások nem jelentenek megoldást a félelemmel és szorongással szemben. Ebben megnevezhetetlen félelemben társa árvacsáthnak a Wilhelm-dalok lírai énje, 
a vidéki orfeuszként megnevezett falu bolondja, aki, noha állandóan mozgásban van, beszéde a folyamatos járkálást viszi színre, útjai nem vezetnek ki az egy helyben járás időtlen és tér nélküli labirintusából:

ne gyere vissza

miért vacogsz kérdem

didergek mondja

ordasgyuruben kistál kocsonya

miért dideregsz kérdem

félek mondja

félek visszajönni amerikából

de hát ki se mentél mondom

félek

még így is félek visszajönni mondja

itt gubbasztok a budin már hónapok óta

látom karcolja

a buditető vasrózsája a bárányfelhőket

és a karcolt bárányfelhők felvéreznek

vérben fürdetnek bennünket

mint a suhogó mozivászon a vak vigh tibikét

akkor mondom tényleg nincs más megoldás

ne gyere vissza

ne gyere vissza ha ki se mentél

(Tolnai, 1992b, 142. o.)

\section{Irodalomjegyzék}

Bányai János (1973): A semmiségek custosa. (Tolnai Ottó: Gogol halála.) Magyar Szó, 88. sz. 12, kötetben: uö: Könyv és kritika. Forum, Újvidék. 57-60.

Fekete J. József (2010): Szikarcnyi kisvilágok. Forrás, 6. sz. 21-24.

Thomka Beáta (1994): Tolnai Ottó. Kalligram, Pozsony.
Tolnai Ottó (1992): árvacsáth. Orpheusz Kiadó Kft. és Forum Könyvkiadó közös kiadása, BudapestÚjvidék.

Tolnai Ottó (1992): Wilhelm-dalok avagy a vidéki orfeusz. Jelenkor Kiadó, Pécs.

Tolnai Ottó (1995): Rózsaszín flastrom. In: Szajbély Mihály (szerk): Rózsaszín flastrom. JATE Szláv Filológiai Tanszék, Szeged. 61-73. 